УАK 338(100)

ББК 65.5

DOI 10.22394/1682-2358-2018-4-46-51

T.N. Okilov, post-graduate student of Tajik State University of Law, Business and Politics

\section{THE CONFLICT POTENTIAL \\ OF TNCS \\ IN MODERN \\ INTERNATIONAL POLITICS}

The role of TNCs in the organization of conflicts in modern conditions is considered. The subject of study is the conflict qualification, development stages, the role, significance and the place of conflict in the activities of TNCs. It is proved that using the conflict TNCs can affect the political, economic and cultural life of the host countries.

Key words and word-combinations: transnationalism, national interest, conflict, economic crisis, transnational companies.
T.Н. Окилов, аспирант Таджикского государственного университета права, бизнеса и nолитикu (email: bobojon1976@yandex.ru)

\section{КОНФАИКТОГЕННОСТЬ ТРАНСНАЦИОНААЬНЫХ КОМПАНИЙ В СОВРЕМЕН- НОЙ МЕЖАУНАРОАНОЙ ПОАИТИКЕ}

\begin{abstract}
Аннотация. Рассматривается роль ТНК в организации конфликтов в современных условиях. Предметом изучения является квалификация конфликта, этапы его развития, роль, значение и место в деятельности ТНК. Доказывается, что, используя конфликт, ТНК могут повлиять на политическую, экономическую и культурную жизнь принимающих стран.

Ключевые слова и словосочетания: транснационализм, национальный интерес, конфликт,
\end{abstract} экономический кризис, ТНК.

$$
\text { И }
$$
развиваются весьма быстрыми темпами: увеличивается население планеты; природные ресурсы истощаются; на данном фоне увеличивается конкуренџия межАу ТНК, которым становится сложнее работать и требуется вести переговоры с принимающими государствами. Аیя быстрого получения Аоступа к их рынку необходимо более быстрое и эффективное Аля ТНК решение конфликтных ситуаций: «Государства все более утрачивают национальный контроль наА развитием ТНК, которые пока что "соглашаются" 
подчиниться существующему порядку (праву), в то время как эффективного межАународного контроля их деятельности еще не созАано» [1, с. 45] .

По определению понятия кросскультурности, данному Ика Ниа Мба, «ТНК становятся более кросскультурными, то есть в ТНК могут работать мюди разных наџиональностей, где вопрос о наџиональной принадлежности или идентичности будет стоять на втором плане» [2]. THК заинтересованы в привлечении мюдей из разных стран и регионов мира Амя всеобщей унификации не по национальным признакам, а с точки зрения получения доступа к разным рынкам. ТНК имеют полномочные представительства, региональные офисы, дочерние компании во множестве стран мира, тем не менее все эти учреждения управляются головным офисом или несколькими офисами из разных точек мира. По данным Инвестопедии (Investopedia) 2014 г., почти все крупные ТНК являются американскими или японскими [3]. Соответственно, необходимо разделить ТНК на две большие группы по ведению деятельности: THК с азиатским укцоном и ТНК с европейским уклоном. В их деятельности выявляется значительная разница: ТНК с азиатским уклоном проводит более мягкую наступательную интервенционную политику по отношению к принимающим странам; вторая группа, наоборот, ведет более жесткую, бескомпромиссную борьбу.

Слово «борьба» уже означает конфликт: ТНК, за которыми стоят влиятельные политики, финансисты, руководители различных государственных организаций, ведут жесткую борьбу за получение доступа на рынки принимающих стран, что вполне заметно на примере ирано-иракской войны, во время которой США поставмяли Ираку технологии двойного назначения, оружие, произведенное не в США, и экономическую помощь в размере мимлиарда домларов, а в Иран - амуниџию по зашите от химического оружия; позже бымо организовано нападение, в ходе которого более 200 тысяч иранџев были убиты и искамечены [4].

Аюбая война выгодна в первую очередь ТНК, прямо или косвенно имеющим отношение к ее организаџии и ведению. Согласно исследованиям, проведенным Швейцарским федеральным технологическим институтом в Цюpихе (Swiss Federal Institute of Technology), основу всех ТНК составмяют финансовые группы, имеющие большое влияние на мировую экономику. Анамиз деятельности данных групп показывает, что из 147 «суперорганизаций» большинство являются финансовыми институтами. К крупным финансовым организациям относятся «Barclays», «J.P. Morgan», «Goddman Sachs», «Morgan Stanley», «Bank of America», «Deutch Bank» и Аругие. Эти финансовые организаџии контролируют $40 \%$ корпоративного богатства планеты, то есть менее $1 \%$ населения Земли фактически контролируют 99\% ее богатств.

Политика не составляет основную цель деятельности ТНК, но им необходимы механизмы ее контроля, влияния или формирования. Соџиальное манипулирование властью не связано с продвижением ими собственных экономических интересов. По мнению исследователей, данная модель управления мировой экономикой содержит в себе большой риск, особенно в возникновении финансовых кризисов. Появление проблем в одной из этих мегаорга- 
низаций, как правило, приводит к их Аальнейшему распространению. Таким образом формируется «эффект» домино, порождающий кризис всей системы мировой экономики. Примером может служить глобальный финансовый кризис 2008 г., когда компания «Lehman Brothers» попала в стадию нестабильности.

В деятельности ТНК, однако, существует и другая сторона медали, когда кризис сознательно провоцируется оАной из них Аля сохранения общественного контроля наА ситуацией, не допускающей возможности вести независимую политику Аля стран и континентов. Цель организаџии международного конфликта Амя ТНК, начиная от «цветных» революџий и заканчивая мокамьными войнами, - управление странами посреАством внеАрения в них своих правиц ведения бизнеса. По существу, большинство конфликтов происходит в тех регионах мира, где ТНК имеют больше интересов или наблюдается их пересечение. К данным регионам в первую очередь можно отнести страны, богатые природными ресурсами (например, регион БАижнего Востока), реАкоземельными полезными ископаемыми, а также Центральную Африку.

По мере возникновения и продолжения мировых и наџиональных финансовых кризисов происходит распределение соџиальных ролей по степени соџиальной эффективности (выигрышности): тем, кто находится в выигрыше, кризис приносит прибыль, а те, кто в проигрыше, должны компенсировать свои потери. Аля компенсации потерь они начинают искать выход, способствующий выбору стран, где можно быстро получить доход. Наличие стабильности в какой-либо из этих стран - повод Аля создания хаоса в качестве условия нагнетания страха, а хаотизация общественных процессов составляет основу формирования управцяемости им: тот, кто управмяет хаосом, управляет и страхом. Управляемый хаос - эта политическая теория и практика, используемые в большинстве случаев США с џелью погружения Аругих стран в нестабильное состояние посредством организации гражданских войн, межнаџиональной напряженности, экономических, продовольственных проблем, коррупџии и формирования иных антисоџиальных патомогий. Аанный механизм обычно разрабатывается и внеАряется при помощи специальных служб, через дипломатический корпус за рубежом и вооруженные силы. ПосреАством формирования управляемого хаоса США могут сохранять определенный контроль наА принимающей страной и получать необходимую выгоду через свои ТНК, выкачивая человеческие, финансовые и сырьевые ресурсы, что позволяет поднимать уровень жизни у себя в стране за счет снижения у Аругих.

В создании мюбого управляемого хаоса и конфмиктов большую роль играют СМИ, обоснованно считающиеся четвертой властью. В СМИ западных стран, в том числе США, распространение цожных сведений, или фейковых новостей, считается нормальным явлением, это делается в первую очередь Аля формирования общественного мнения вокруг проблем конкретной страны или множества стран для реализации в дальнейшем задуманного плана. ОАин из примеров этого - ракетные удары по городам Сирии якобы из-за применения химического оружия сирийскими правительственными войсками. В ^юбом обществе можно найти группу недовольных мюдей, находящихся в 
оппозиции к мюбой власти; их условно можно назвать потенциальными провокаторами ики деструктивными симами.

В Большой советской энциклопедии слово «деструкция» определяется как «нарушение, разрушение нормальной структуры чего-либо». Э. Фромм в книге «Анатомия человеческой Аеструктивности» слелац глубокий анализ философского понимания природы агрессивности и разрушительного начала в человеке [5]. Изначальное наличие деструктивности в человеке обусловливает

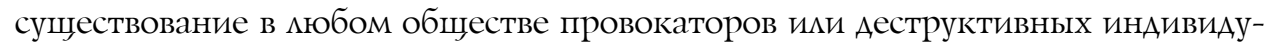
умов, имеющих официальную государственную регистрацию в принимающей стране. Аця достижения заранее поставценной цеми необходимо получение финансовой подпитки от НПО. Аанная группа будет муссировать заранее распространенную через СМИ фейковую новость. Эта схема особенно работает в условиях избирательного процесса в рамках конкретной страны, и для ТНК данные выборы будут иметь большое значение Аля получения доступа к рынкам сбыта. Провоцируя общество, можно организовать государственный переворот или войну. Ярким примером тому явмяется Украина, где был широко задействован механизм политических технологий. Используя его, можкно сменить мюбого мидера, и через подлержку фиктивных выборов поставить во главе государства политика, проводящего интересы ТНК.

Предоставление политических консультаций или советов, использование различных избирательных технологий, моббирования ици технологий по связям с общественностью составцяют политическую технологию, широко используемую как один из методов организаџии войны и государственных переворотов на мировом уровне. Принимающей стране предоставцяются политические консультации ици советы во время предвыборной кампании или принятия судьбоносных Аля страны решений с привлечением крупных аналитических центров, что, в свою очередь, определяет степень вцияния местной политической элиты на политический процесс в государстве. Используя метод моббирования интересов тех ими иных групп в обществе, ТНК могут Аостичь цели в получении необходимого результата, при условии широкого применения средств связи Аця «промывки мозгов» и Аостижения цеки.

Аля раскрытия механизмов продвижения интересов ТНК весьма поучителен пример Аемократической Республики Конго (АРК). Это одна из богатейших стран Центральной Африки с изумительно красивой природой, но главное - нацичием колтана, полезного химического элемента, необходимого Аля цифрового развития экономики. Ни один гаджет в настоящее время не может быть создан без использования данного элемента. Согласно исследованиям GSMA (The Mobile Economy), в 2015 г. количество пользователей мобильными устройствами равнялось 3,5 мирА, к 2020 г. ожкидается их рост до 4,6 мира [6]. Конго на треть обеспечивает им мир. Цена кимограмма колтана на западных и азиатских рынках достигает несколыких тысяч Аомларов, а местное население получает пару домларов за работу в течение месяца. Местные бандформирования и повстанческие группы из сосеАних стран, например Руанды, обеспечиваемые оружием со стороны ТНК, веАут войны, устраивают 
резню, геноџиА и политический террор местных родов и пиемен, освобождая Аля себя земли, богатые колтановыми залежами.

С 1996 г. в Конго Алится мокальный конфликт, уже унесший жизни окомо 5,4 млн мюдей. Вторая волна конфмикта началась в 2008 г., когда по всему миру прокатился финансовый кризис. Тем не менее мировое сообщество посчитало его цокальным и не признало роли ТНК в эскалации напряженности в регионе. В октябре 2002 г. группа экспертов Организации Объединенных Наџий обвинила 85 компаний Организаџии экономического сотрудничества и развития в нарушении основных принципов эксплуатаџии национальных природных ресурсов АРК. В ноябре 2004 г. группа бельгийских НПО подаАа жалобу на Cogecom и три Аругие бемьгийские компании, обвинив их в незаконной эксплуатации природных неАр $А$ PК и участии Cogecom в колтановой торговле. По сообщению группы, колтан импортировался из АРК в Бельгию через Руанду, а Cogecom непосредственно участвовала в финансировании повстанческого движения RCD-Goma [7]. Согласно докладу OOH, незаконная эксплуатация национальных природных богатств Конго, включая месные ресурсы, происходит с угрожкаюей скоростью. ОАнако, в соответствии с офищиальной позицией Всемирного фонда дикой природы (WWF), такой проблемы не сушествует, видимо, потому, что данная организаџия регумярно проплачивается ТНК и защищает их интересы.

Конфликт в АРК поддерживается вооруженными группировками из сосеАних стран, Уганда и Руанда через собственные подставные компании имеют прямой доступ к колтановой добыче. Следовательно, причиной возникновения конфАиктов в $А$ РК явцяется в первую очередь столкновение экономических интересов ТНК, вслеАствие чего возникают и политические разногласия. Крупнейшие ТНК сосредоточены в США, они располагают огромными финансовыми и военными ресурсами.

Установление международного взаимопонимания искмючает необходимость взаимной обороны, что парадоксальным образом, по закону обратного действия, делает английскую политическую доктрину "разделяй и властвуй» весьма актуальной: мелкие территории мегко подвергаются манипулированию со стороны крупных держав. Примером явмяются Индия и Пакистан, на протяжении многих цет неспособные разрешить Кашмирский конфцикт.

Интересы ТНК в области оборонной промышленности связаны с реальными доходами, получаемыми при отработке нового вооружения во время межАународных военных конфциктов. Великобритания, США явцяются главными источниками создания и финансирования военных конфликтов в мире. Политическая система США, напрямую зависящая от моббирующих групп, Аолжна учитывать их интересы, в ином случае политика мюбого первого миџа государства не достигнет своей цели, что исключит также возможность бамлотироваться на следующий срок.

THК заинтересованы в организации конфмиктов прежде всего в странах, богатых природными ресурсами или занимающих стратегически важное положение в мире и регионе. Аیя этого создаются конкретные условия: осушествляется финансовая поддержка конфликтующих сторон, включая их организаџию; им 
поставцяются военные товары и услуги, в том числе консалтинговые - отправка военных советников, помощников и т.п.

Многие крупные ТНК США в поисках рынков сбыта оружия способствуют созданию конфликтов в «горячих точках» планеты». Это страны Ближнего Востока, где много мет существует приграничный конфцикт межАу Пацестиной и Израилем; религиозный конфликт между Саудовской Аравией и Ираном; межккановые войны в Афганистане. где уже более сорока мет идет «непонятная» война, и ставшем удобным полигоном Аля испытания новейших видов вооружения в полевых условиях. Страна служит источником наркотрафика в Россию и западные страны. Нестабильность в Афганистане и угроза терроризма расширяют рыночные возможности (конкурентоспособность) ТНК, при этом общественное сознание промывается через подставные СМИ.

Таким образом, конфликт включает в себя несколько важнейших этапов и составцяет основу развития общества, связанную с его использованием по направлению, необходимому Аля достижения поставценной цели. Конфцикт организуется, планируется и контролируется отдельными общественными группами или странами в своих интересах. Организованный конфликт - среАство получения ТНК доступа на рынок принимающей страны с целью получения сверхаоходов.

\section{Библиографический список}

1. Владимиров А.И. «Железная пята ТНК»: глобализация, война и мир третьего тысячелетия // Пространство и время. 2012. № 1 (7).

2. Ika Nia Mba. Journal of International Business and Economics. Published by American Research Institute for Policy Development. 2015. T. 3, № 1. P. 86-92.

3. Multinational Corporation. MNC. URL: https://www.investopedia.com/terms/m/multinationalcorporation.asp

4. Белоусова К.A. Ирано-иракская война (1980-1988 гг.) и политика CША в Ираке. URL: https://cyberleninka.ru/article/v/irano-irakskaya-voyna-1980-1988-i-politika-ssha-v-irake

4. Фромм Э. Анатомия человеческой деструктивности. М., 1994.

5. Mobile Economy 2017. URL: https://www.gsma.com/mobileeconomy/

6. Belgian companies illegal resource exploitation in DRC. URL: https://www.oecdwatch.org/ cases/Case_65

7. Зайцев С.Ю. Взаимодействие транснациональных корпораций и государства: политологический анализ // Вестник Поволжского института управления. 2017. Т. 17, № 6. С. 37-45. 